\title{
Алгоритм лікування первинного зміщення надколінка у спортсменів: огляд літератури
}

\author{
I. М. Зазірний, В. Г. Євсєєнко
}

Центр ортопедії, травматології та спортивної медицини Клінічної лікарні «Феофанія» ДУС, Київ, Україна

\begin{abstract}
Резюме. Первичное смещение надколенника остается актуальной проблемой, с которой сегодня сталкиваются врачи. Эти широко распространенные повреждения имеют значительный уровень повторения. Было описано огромное количество оперативных и неоперативных методов лечения этих повреждений, но в литературе недостаточно доказательной базы. Нами изучены материалы PubMed c 1970 до 2010 г. относительно смещения надколенника, в том числе клинические проявления, течение болезни, рентгенологические исследования и особенности лечения.

Первичное обследование при смещении надколенника включает изучение анамнеза болезни, клиническое обследование и рентгенографию. При наличии признаков смещенного остеохондрального фрагмента или гемартроза необходимо сделать магниторезонансное обследование. Лечение первичного смещения надколенника вызывает дискуссии, а преимущества раннего оперативного вмешательства не были продемонстрированы ни в одном исследовании.

При лечении первичных смещений надколенника у спортсменов следует применять консервативные методы, за исключением случаев, когда обнаружены остеохондральные фрагменты.
\end{abstract}

Ключевые слова: смещение надколенника, нестабильность, лечение.

Summary. Primary patellar dislocation remains a pressing problem facing doctors today. This widespread injury has a significant rate of recurrence. A huge number of surgical and non-surgical methods were described for treatment of these injuries, but there is no enough evidence $i$ $n$ the literature.

We studied the materials of PubMed from 1970 to 2010 concerning the patella dislocation, including clinical manifestations of the disease, $X$-ray examinations and features of the treatment. Initial examination of a patella dislocation includes a history, physical examination, and radiographs. If there is evidence of a displaced osteochondral fragment or hemarthrosis, then magnetic resonance imaging should be obtained. The treatment of first-time patella dislocations has been controversial, and no study has demonstrated a clear benefit to early operative $i$ ntervention.

First-time patellar dislocations should be treated conservatively unless there is evidence of a displaced osteochondral fragment.

Key words: patella dislocation, instability, treatment.

Лікування первинних зміщень надколінка залишається актуальним питанням. Гостре зміщення надколінка - поширена травма, 3 якою стикаються спортивні травматологи, - супроводжується тривалим періодом непрацездатності й високим рівнем рецидивів $[6,9,10]$. Ми не зустрічали в доступній літературі алгоритму, в якому надається структурований підхід до таких пацієнтів, тому і провели дане метадослідження для виявлення сучасних тенденцій до лікування спортсменів з первинним латеральним зміщенням надколінка.

Епідеміологія та перебіг хвороби. Середня кількість випадків первинного зміщення надколінка складає 58 випадків на 10000 населення за рік, а найвищий рівень захворюваності припадає на вікову групу з 10 до 17 років (у цій віковій групі спостерігається до 29 випадків на 10 000) [9]. У більшості цих пацієнтів не виникатиме подальшої нестабільності суглоба, оскільки, за різними даними, частота рецидиву після консервативного лікування складає 15-44 \% $[6,9,10]$. I хоча повторне ураження $\epsilon$, скоріше, виключенням, ніж правилом, багато пацієнтів продовжуватимуть відчувати симптоми після цих випадків. Atkin зі співавторами [2] помітили, що через 6 місяців після травми $58 \%$ пацієнтів 
продовжують відчувати обмеження під час фрізичного навантаження, а у 55 \% випадків пацієнти не повертаються до спортивної кар'єри. 3 цих причин ідея хірургічного втручання підтримувалась, як спроба зниження частоти рецидивів, що призвело до полеміки та плутанини щодо показань до операції у гострих випадках.

Ми багато дізнались про перебіг процесу первинного зміщення надколінка. Більшість літературних джерел містить дослідження серій випадків та демонструє досвід одного автора, тому повноцінне порівняння $€$ проблематичним. Останнім часом було опубліковано декілька проспективних досліджень, які допомагають у прийнятті клінічних рішень $[4,5,14,15,18,19] .3$ урахуванням цих публікацій алгоритм, представлений у нашій статті, веде лікаря-клініциста від обстеження до лікування пацієнтів з первинним зміщенням надколінка.

Початкове обстеження. Початкове обстеження має включати детальний збір анамнезу та клінічний огляд, щоб пересвідчитись у тому, що зміщення надколінка мало місце, а також для виключення інших ушкоджень - розриву передньої хрестоподібної зв'язки та медіальної колатеральної зв'язки, які мають схожий механізм ушкодження. Основні види діяльності, що призводять до зміщення надколінка - це спорт (61 \%) та танці (9\%) [9]. На відміну від точки зору, що існувала раніше, найчастіше таких уражень зазнають не пасивні пацієнтки жіночої статі, які мають зайву вагу, а навпаки, молоді спортсмени будь-якої статі, при цьому частота первинних зміщень однакова серед жінок і чоловіків [9]. Особливу увагу необхідно приділити визначенню того, чи зазнавав раніше пацієнт первинного зміщення в ушкодженому або протилежному колінному суглобі. Наявність в анамнезі фракту зміщення надколінка в протилежному суглобі підвищує ризик повторного зміщення в травмованому у шість разів, так само як і попередні зміщення надколінка на травмованому суглобі [9].

При обстеженні зазвичай виявляється великий набряк, біль по медіальній поверхні суглоба. Ці ознаки не $є$ специфрічними, тому необхідно провести ретельний огляд, щоб виключити пошкодження хрестоподібних та бокових зв'язок, ротаційної нестабільності, а також болючість по ходу лінії суглоба. Також потрібно провести Лахман-тест, артрометрію зв'язок, оцінку активної функції чотириголового м'яза стегна, оцінку цілісності колатеральних зв'язок.

Незважаючи на біль і страх хворого після травми, клінічного обстеження має бути достатньо, щоб підтвердити діагноз у більшості пацієнтів, котрі звертаються до лікаря 3 гострим посттравматичним гемартрозом колінного суглоба, включаючи випадки зі зміщенням надколінка. Клінічне дослідження має включати оцінку вісі нижньої кінцівки та м'яких тканин, що оточують колінний суглоб.

Великий напружений набряк суглоба $є$, найвірогідніше, гемартрозом. У цьому випадку можна провести пункцію суглоба, щоб переконатися у наявності у ньому крові, послабити больовий синдром, спростити клінічне дослідження, зменшивши напруження м'яких тканини навколо суглоба. Виявлення гемартрозу може свідчити про остеохондральний перелом. На рентгенограмах такі переломи визначаються важко, у цих випадках магніторезонансна томографрія (МРТ) дозволяє більш точно оцінити стан суглобових поверхонь [7, 11, 22]. У $95 \%$ хворих з первинним зміщенням надколінка виявляється пошкодження суглобового хряща [16].

Інструментальна діагностика. Всім хворим, що звертаються за медичною допомогою з травмою коліна та набряком, у яких підозрюється нестабільність надколінка, необхідно виконати рентгенограми в передньо-задній, боковій та аксіальній (Merchant чи Laurin) проекціях. Якщо на звичайних рентгенограмах виявляються остеохондральні переломи, це свідчить про значне пошкодження хряща. Тому необхідно провести МРТ, щоб точніше визначити патологію, або лікар має визначитись з необхідністю ургентної операції. Навіть якщо на рентгенограмах не виявляється патологія, не можна виключати остеохондральний перелом. За наявності в цьому випадку гемартрозу необхідна МРТ для уточнення діагнозу, бо лише МРТ надійно демонструє наявність остеохондрального пошкодження у разі первинного зміщення надколінка [8].

Хірургічне втручання виправдане, якщо на МРТ видно остеохондральне вільне тіло значного розміру, яке підлягає фріксації. У літературі немає визначення розміру фррагменту, який піддається фріксації, але необхідно, щоб фрагмент містив субхондральну кістку розміром принаймні 9 мм. За наявності меншого остеохондрального фррагменту хірургічне втручання не вважається терміновим. Подальше спостереження за пацієнтом часто необхідне з метою визначення, чи відбувається покращення фрункції колінного суглоба, чи розвивається симптоматика вільного внутрішньосуглобового тіла. Ми не знайшли в літературі підтвердження, що наявність лише остеохондрального дефекту - за відсутності вільного тіла, достатньо великого для виправдання 
репозиції та фріксації - $є$ чітким показанням для оперативного втручання. У випадку нормальної рентгенограми, за відсутності гемартрозу, ймовірність значного остеохондрального перелому невелика, і можна продовжувати спостерігати пацієнта в клінічних умовах без МРТ.

У гострих випадках МРТ може використовуватись для оцінки цілісності звуження м'яких тканин. Ушкодження медіальних утримуючих структур та медіальної надколінно-стегнової зв'язки (МНС3) зустрічаються часто та можуть мати значення для прогнозу. Ушкодження МНСЗ з боку стегна може призвести до нестабільності надколінка, хоча залишається неясним, чи вплине відновлення МНСЗ на покращення довготривалих клінічних результатів в цьому випадку [20].

Хірургічне лікування. Ушкодження поверхні суглоба відбуваються часто, але здебільшого відсутні значно зміщені фрагменти. Найменш дискусійним показанням до оперативного втручання після гострого первинного зміщення надколінка $\epsilon$ великий остеохондральний перелом зі зміщенням та вільним тілом, яке може бути зафріксовано. Фрагмент кістки вважається придатним до фріксації, якщо він вміщує щонайменше один чи два абсорбуючі штифтти. Зазвичай фррагменти закріплюють і трьома 2 мм штифтами. Nomura et al. [16] виконали артроскопічне обстеження суглобової поверхні у 39 випадках первинного зміщення надколінка: у 37 випадках (95 \%) спостерігалось ушкодження суглобового хряща, серед яких у 23 \% були наявні тріщини надколінка, у $72 \%$ - остеохондральні та хондральні переломи. Цікаво, що у $31 \%$ спостерігались ушкодження хряща латерального стегнового виростка. При ушкодженні суглобового хряща не завжди виправдане хірургічне втручання. Хоча, дійсно, повернення у анатомічне положення та стабілізація остеохондральних фррагментів у гострих випадках здаються логічними, якщо фррагменти мають достатній розмір, щоб бути зафіксованими. Менші фрагменти, які не піддаються фріксації, вимагають лікування, тільки якщо вони являють собою симптоматичні вільні тіла.

При фріксації остеохондральних фррагментів можна провести відновлення медіальних структур, в тому числі МНСЗ. Такі структури відновлюють лише тоді, коли необхідна артротомія для фіксації остеохондрального перелому. Це не означає, що така операція призводить до значного зниження рівня розповсюдження ушкодження, але вона може покращити функціональність МНСЗ завдяки обмеженню надмірного латерального зміщення надколінка. Однак для підтримки цієї рекомендації бракує доказів.
Через високу частоту ушкоджень суглобового хряща після первинного зміщення надколінка деякі хірурги радять проводити стандартну артроскопію, але це залишається суперечливим питанням. У 2003 р. під час щорічного зібрання Міжнародної групи з вивчення надколінно-стегнового суглоба [4] учасники дійшли згоди, що стандартна артроскопія не показана у випадках первинного зміщення надколінка. Натомість, для пацієнтів з високим ризиком було рекомендовано проведення МРТ-дослідження, що обумовлено великим гемартрозом.

Окреме питання - чи необхідно терміново оперувати первинні зміщення надколінка задля зниження ризику виникнення нестабільності у майбутньому. I хоча література переповнена описами досліджень серій випадків як оперативного, так і консервативного лікування первинного зміщення надколінка, контрольованих рандомізованих досліджень проводилось дуже мало $[1,3-5,10,14-17,19,21]$.

Buchner зі співавт. [3] провели ретроспективне дослідження 126 пацієнтів в середньому через 8,1 років після первинного зміщення надколінка. 3 них 37 особам було виконано термінове хірургічне відновлення парапателярних комплексів зв'язок. При подальшому спостереженні не виявлено значної різниці у частоті повторних зміщень, рівні активності, функціональних та суб'єктивних результатах між пацієнтами, яких лікували оперативним та неоперативним шляхом. Nikku зі співавт. [14, 15] спочатку опублікували дворічні, а згодом і семирічні результати проспективного рандомізованого дослідження. Вони не виявили жодної різниці в оцінках результатів лікування та частоті виникнення нестабільності суглоба між цими двома групами у будь-який проміжок часу.

В роботі Sillanpaа зі співавт. [19] наведено результати проспективного рандомізованого дослідження стабілізуючої операції з приводу первинного травматичного зміщення надколінка. Було відібрано 40 пацієнтів у довільному порядку для первинної стабілізуючої операції, також було сорормовано групу для консервативного лікування (до якої потрапили ті пацієнти, яким виконували артроскопічну операцію з видалення остеохондральних фррагментів), що підлягали післяопераційному спостереженню в середньому протягом семи років. Пацієнтам в хірургічній групі виконували або плікацію або операцію РуГолдсвайта (Roux-Goldthwait procedure), в залежності від рішення хірурга. Частота повторного зміщення у групі консервативного лікування склала 27 \% на відміну від 0 \% в групі стабілізуючої операції. Незважаючи на меншу кількість 
повторних зміщень в хірургічній групі, суб'єктивні показники шкали Kujala та рівень активності були однаковими в обох групах.

Також недавно було опубліковано результати двох інших рандомізованих контрольованих досліджень, в яких порівнювались неоперативне лікування та відновлення медіальної надколінно-стегнової зв'язки (МНСЗ) при гострому зміщенні надколінка. Автори [5] розподілили у довільному порядку 80 пацієнтів 3 первинним зміщенням надколінка в середньому через 50 діб після ушкодження - на хірургічну групу та групу з ортопедичними апаратами (брейсами). Хірургічна техніка, яка застосовувалась для всіх пацієнтів, - прикріплення за допомогою фріксаторів до медіального надвиростка стегнової кістки. Частота повторних ушкоджень склала 17 і $20 \%$ в хірургічній та консервативній групах відповідно, що не становить значної різниці, 3 урахуванням кількості учасників. У цьому дослідженні вважається, що розрив МНСЗ відбувається на медіальному надвиростку стегнової кістки, причому автори не намагаються визначити місце розриву МНСЗ у пацієнтів хірургічної групи.

Camanho зі співавт. [4] при проведенні подібного дослідження звертали увагу на місце розриву МНСЗ при гострому зміщенні надколінка: у восьми гострих випадках зміщення відновлювали MHCЗ на місці ушкодження за даними МРТ, при цьому не виявлено жодних повторних ушкоджень - у порівнянні з 50 \% повторень у групі консервативного лікування, із середнім періодом спостереження у 40,4 місяці. Із 17 пацієнтів хірургічної групи 10 осіб мали ушкодження МНС3 біля надколінка, а 7 - біля стегнової кістки. Ці результати наводять на думку про те, що хірургічне відновлення окремого ушкодження МНС3 при гострому зміщенні може знизити ризик повторної травми. Такі результати не були підтверджені, хоча це перший опублікований доказ першого рівня, який вказує на те, що негайне хірургічне відновлення може покращити стан після первинного зміщення надколінка.

Для того щоб пропонувати первинне хірургічне лікування для стабілізації надколінка, необхідно мати достатню кількість доказів того, що стан пацієнта може покращитись саме завдяки хірургічному втручанню, але сьогодні немає чітких підтверджень цього. Проведення хірургічної стабілізації надколінка після первинного випадку зміщення наразі не рекомендується. Набагато більший ризик повторного зміщення існує після другого зміщення (49 \%), і в цьому випадку можна розглядати можливість проведення операції [9].
Консервативне лікування. Існує дивовижно мало інформації про консервативне лікування первинного зміщення надколінка. Сучасні схеми лікування пропонують великий обсяг: від негайної іммобілізації без ортопедичного апарата (брейса) до іммобілізації випрямленої кінцівки гіпсовою пов'язкою протягом шести тижнів. Іммобілізація випрямленої кінцівки може забезпечити кращі умови зцілення для медіальних структур, особливо МНСЗ, але це досягається за рахунок послаблення стійкості та втрати контролю над проксимальним відділом кінцівки, що часто супроводжують тривалу іммобілізацію. Дотримання пацієнтом вказівок лікаря також може бути фрактором на користь неоперативного лікування. 3 цих причин багато клініцистів радять проводити короткострокову іммобілізацію, потім реабілітацію коліна 3 надколінковим ортезом або без нього. Автори [12] вивчили це питання глибше, розділивши 100 пацієнтів 3 первинним зміщенням надколінка на три групи за методами лікування: пов'язка (або ортез) на надколінку, задня шина або гіпсова пов'язка. Іммобілізація у другому та третьому випадках тривала шість тижнів. Повідомлялось про зростання ризику повторного зміщення в три рази у тих пацієнтів, яким виконували негайну іммобілізацію. Обмеження об'єму рухів частіше спостерігалось у групі з гіпсовою пов'язкою.

Не проводилось жодних досліджень щодо ефективності фрізіотерапевтичного лікування первинних зміщень надколінка. Також залишається ще вивчити вплив надколінкових ортезів та пластирів (тейпування) на результати лікування первинних зміщень надколінка.

Після першого випадку зміщення, з урахуванням наявних доказів, на деякий час рекомендовано іммобілізацію випрямленої кінцівки, тобто забезпечення пацієнта брейсом для випрямленої кінцівки на шість тижнів, потім фрізіотерапевтичні методи та ЛФК, орієнтовані на розширення об'єму рухів та укріплення чотириголового м'яза стегна.

Висновки. Лікування первинного зміщення надколінка залишається темою, яка викликає полеміку, але декілька висновків можна зробити.

У випадку наявності гемартрозу необхідно обстежити пацієнта на існування остеохондральних фррагментів за допомогою рентгенографрії та MPT. Зміщені остеохондральні фрагменти, які піддаються фріксації, слід повернути у нормальне положення та стабілізувати.

Негайна хірургічна стабілізація надколінка залишається суперечливим питанням, і переваги її у довгостроковій перспективі не описано в 
літературі. Якщо вибране неоперативне лікування, іммобілізація випрямленої кінцівки протягом шести тижнів здатна забезпечити найменшу частоту повторного ушкодження.

\section{Література}

1. Ahmad C. S. Immediate surgical repair of the medial patella stabilizer for acute patellar dislocation: a review of eight cases. / C. S. Ahmad, B. E. Stein, D. Matuz // Am. J. Sports Med. - 2000. - 28. - P. 804-810.

2. Atkin D. M. Characteristics of patients with primary acute lateral dislocation and their recovery within the first 6 month / D. M. Atkin, D. C. Fithian, K. S. Marangi // Am. J. Sports Med. - 2000. - 28. - P. 472-479.

3. Buchner M. Acute traumatic primary patellar dislocation: long-term results comparing conservative and surgical treatment / M. Buchner, B. Baudendistel, D. Sabo // Clin. J. Sport Med. - 2005. - 15. - P. 62-66.

4. Comanho $G$. Conservative versus surgical treatment for repair of the medial patellofemoral ligament in acute dislocation of the patella / G. Comanho, A. Viegas, A. Bitar // Arthroscopy. - 2009. - 25(6). - P. 620-625.

5. Christiansen S. Isolated repair of the medial patellofemoral ligament in primary dislocation of the patella: a prospective randomized study / S. Christiansen, B. Jacobsen, B. Lund // Arthroscopy. - 2008. - 24(8). P. 881-887.

6. Cofield R. H. Acute dislocation of the patella: result of conservative treatment / R. H. Cofield, R. S. Bryan // J. Trauma. - 1977. - 17. - P. 526-531.

7. Elias D. A. Acute lateral patellar dislocation at MR imaging: injury patterns of medial patellar soft-tissue restraints and osteochondral injures of the inferomedial patella. / D. A. Elias, L. M. White, D. C. Fithian // Radiology. 2002. - 225. - P. 736-743.

8. Engelhardt L. V. How reliable is MRI in diagnosing cartilaginous lesion in patients with first and recurrent lateral patellar dislocations? / L. V. Engelhardt, M. Raddats, B. Bouillon // BMCMuscoloskelet Disord. - 2010. - 11. P. $149-151$.

9. Fithian D. C. Epidemiology and natural history of acute patellar dislocation / D. C. Fithian, E. W. Paxton, M. I. Stone // Am. J. Sports Med. - 2004. - 32. - P. 1114-1121.

10. Hawkins R. J. Acute patellar dislocations: the natural history. / R. J. Hawkins, R. H. Bell, G. Anisette // Am. J. Sports Med. - 1986. - 14. - P. 117-120.

11. Kirsh M. Transient lateral patellar dislocation: diagnosis with MR imaging / M. Kirsh, S. Fitzgerald, H. Friedman // AJR Am Roentgenol. - 1993. - 161. P. $109-113$.

12. Maenpaa H. Patellar dislocation: the long-term results of nonoperative management in 100 patients /
У підсумку цей алгоритм надає оснований на задокументованих доказах підхід, який допоможе лікарю-клініцисту при лікуванні гострого первинного зміщення надколінка.

H. Maenpaa, M. U. Letho //Am. J. Sports Med. - 1997. 25. - P. 213-217.

13. Mehta V. M. An algorithm guiding the evaluation and treatment of acute primary patellar dislocations / V. M. Mehta, M. Inoue, E. Nomura // Sport. Med. Arthrosc. Rev. - 2007. - 15(2). - P. 78-81.

14. Nikku R. Operative treatment of primary patellar dislocation does not improve medium-term outcome: a 7-year follow-up report and risk analysis of 127 randomized patients. / R. Nikku, Y. Nietosvaara, K. Aalto // Acta Orthop. 2005. - 76. - P. 699-704.

15. Nikku $R$. Operative versus closed treatment of primary dislocation of the patella / R. Nikku, Y. Nietosvaara, P. F. Kallio // Acta Orthop. Scand. - 1997. - 67. P. $419-423$.

16. Nomura E. Chondral and osteochondral injuries associated with acute patellar dislocation. / E. Nomura, M. Inoue, M. Karimura // Arthroscopy. - 2003. - 19. P. $717-721$.

17. Sallay P. I. Acute dislocation of patella: a correlative pathoanatomic study. / P. I. Sallay, J. Poggi, K. P. Speer // Am. J. Sports Med. - 1996. - 24. - P. 52-60.

18. Sillanpaa $P$. J. Arthroscopic surgery for primary traumatic patellar dislocation: a prospective, nonrandomized study comparing patients treated with and without acute arthroscopic stabilization with a median 7-year follow-up. / P. J. Sillanpaa, H. M. Maenpaa, V. M. Mattila // Am. J. Sports Med. - 2008. - 36. - P. 2301-2309.

19. Sillanpaa $P$. J. Treatment with and without initial stabilizing surgery for primary traumatic patellar dislocation: a prospective randomized study. / P. J. Sillanpaa, V. M. Mattila, H. M. Maenpaa // J. Bone. J. Surg. Am. - 2009. - 91. P. 263-273.

20. Sillanpaa $P$. J. Femoral avulsion of the medial patellofemoral ligament after primary traumatic patellar dislocation predicts subsequent instability in men: a 7-year nonoperative follow-up study. / P. J. Sillanpaa, E. Peltola, V. M. Mattila // Am. J. Sports Med. - 2009. - 37. P. $1513-1521$.

21. Vainopaa S. Acute dislocation for the patella: a prospective review of operative treatment. / S. Vainopaa, E. Laasonen, T. Silvennoinen // J. Bone. J. Surg. Brit. 1990. - 72. - P. 366-369.

22. Virolainen $H$. Acute dislocation of the patella: MRI findings / H. Virolainen, T. Visury, T. Kuusela // Radiology. - 1993. - 189. - P. 243-246.

Надійшла 06.05.2013 